Revista Mídia e Cotidiano

Artigo Seção Livre

Volume 12, Número 1, abril de 2018

Submetido em: 16/03/2018

Aprovado em: 28/04/2018

\title{
PARRESÍA JORNALÍSTICA: a fala franca de Juremir Machado da Silva no embate discursivo com Luis Fernando Verissimo no texto de opinião
}

\section{JOURNALISTIC PARRESÍA: the frank speech of Juremir Machado da Silva in the discursive encounter with Luis Fernando Verissimo in the opinion text}

\author{
Eduardo RITTER ${ }^{1}$
}

\section{Resumo:}

Nos últimos anos de vida, o filósofo francês Michel Foucault ministrou uma série de cursos no Collège de France, sendo que um dos temas dessas falas foi o conceito da palavra grega parresía que, resumidamente, significa assumir riscos por falar com franqueza no espaço público. Destarte, o artigo traz algumas reflexões sobre essa prática no jornalismo, especialmente através de textos jornalísticos. Valendo-se da própria perspectiva de discurso de Foucault, são observados dois textos de um jornalista brasileiro que fez uso da sua parresía e que pagou por isso: "O sistema dos intocáveis" e "Um caso pessoal, ou em nome do filho", de Juremir Machado da Silva. Nos dois textos, o autor revela a polêmica que teve com o escritor Luis Fernando Verissimo e que resultou na saída de Machado da Silva do jornal Zero Hora nos anos 1990.

Palavras-chave: Parresía; Jornalismo opinativo; Fala franca; Discurso; História do jornalismo.

\begin{abstract}
:
In the last years of life, the French philosopher Michel Foucault taught a series of courses at the Collège de France, one of the themes of which was the concept of the Greek word parresia, which means to take risks by speaking frankly in public. Thus, the paper brings some reflections about this practice in journalism, especially through opinion journalistic texts. Using the perspective of Foucault's discourse, two texts wrote by a Brazilian journalist are observed who used his parresia and who paid for it: The system of the untouchables"and 'A personal case, or in the name of the child"by Juremir Machado da Silva. In both texts, the author reveals the controversy he had with the writer Luis Fernando Verissimo, which resulted in the departure of Machado da Silva from the newspaper Zero Hora in the 1990s.
\end{abstract}

Keywords: Parresia; Journalism; Opinion; Free Speech.

\footnotetext{
${ }^{1}$ Professor do Departamento de Ciências da Comunicação da Universidade Federal de Santa Maria (UFSM), campus Frederico Westphalen. Doutor em Comunicação Social pela PUCRS com período PDSE na New York University (Estados Unidos).
} 


\section{CONSIDERAÇÕES INICIAIS}

Na Grécia Antiga (2000 a.C. - 146 a.C.) surge e se desenvolve o conceito de parresía $^{2}$, que sinteticamente significava falar a verdade no espaço público assumindo riscos por adotar tal atitude. O conceito é aprofundado por Foucault em seus cursos no Collège de France no início dos anos 1980. Em tese de doutorado, apliquei o conceito de parresía à prática da reportagem, tendo como objeto de estudo a vida e obra do jornalista estadunidense Hunter S Thompson (1937-2005), criador de um estilo polêmico e irreverente de texto que ficou conhecido como jornalismo gonzo. Agora, neste artigo, trabalho com a mesma perspectiva de pensar a parresía aplicada ao Jornalismo, no entanto, o foco nesse estudo são os textos opinativos, tendo como objeto um autor brasileiro: Juremir Machado da Silva.

Obviamente a vida e obra de Machado da Silva renderiam uma análise com centenas de páginas, portanto, optei por fazer um recorte de dois textos específicos, ambos publicados no livro A miséria do jornalismo brasileiro (MACHADO DA SILVA, 2000): "O sistema dos intocáveis" e "Um caso pessoal, ou em nome do filho". Em ambos, Machado da Silva comenta a polêmica em que se envolveu com o escritor Luis Fernando Verissimo, sendo que na época da discórdia ambos eram colunistas do jornal Zero Hora. Fazendo uso de sua parresía, Machado da Silva pagou caro por usar a fala franca no espaço público: acabou perdendo o emprego no jornal de maior circulação do estado brasileiro do Rio Grande do Sul.

Destarte, observo o discurso adotado por Machado da Silva para abordar o episódio, fazendo, mais uma vez, o uso de sua parresía. Vale destacar que, assim como Foucault deixou claro em seus cursos, o estudo sobre a parresía não consta em analisar somente as formas de discurso da maneira como ele é reconhecido e assumido como verdadeiro, mas "sob que forma, em seu ato de dizer a verdade, o indivíduo se constitui e é constituído pelos outros como sujeito que pronuncia um discurso de verdade, sob que forma se apresenta, a seus próprios olhos e aos olhos dos outros, quem diz a verdade" (FOUCAULT, 2011, p. 4). E o texto do jornalismo opinativo é, contemporaneamente,

\footnotetext{
${ }^{2}$ Optei pela grafia parresía, pois ela é escrita de diferentes maneiras, inclusive nas obras de Michel Foucault em que ele aborda o termo grego. Sigo a justificativa apresentada pelos editores da obra O Governo de si e os Outros, que usam o seguinte argumento: "optou-se por manter a forma grega transliterada, conforme o original francês e não a vernácula" (FOUCAULT, 2010b, p. 8).
} 


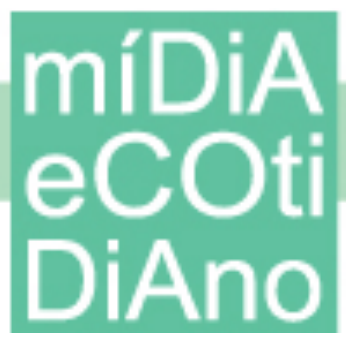

uma das principais formas do autor jornalista expor essa verdade, independentemente da plataforma em que é publicado.

Feita a apresentação do tema, estabeleceu-se a seguinte questão norteadora de pesquisa: quais são as características do texto de Juremir Machado da Silva e como ele se torna (ou não) um texto caracterizado como parresía jornalística? Para tanto, o artigo está dividido em três partes principais. Inicialmente, apresento de maneira breve o conceito de parresía a partir dos cursos ministrados por Foucault, já elucidando a ideia de parresía jornalística. Posteriormente, de maneira bastante sucinta, caracterizo Juremir Machado da Silva como um jornalista que faz uso de textos de opinião, mais especificamente da crônica e do comentário. Por fim, faço a análise dos dois textos escolhidos para serem analisados neste artigo.

Metodologicamente, optei por processos abertos, partindo das premissas de Feyerabend (2003), que ressalta que nenhuma escolha metodológica deve ser ignorada durante a realização da pesquisa, salientando que a definição prévia de uma metodologia fechada pode privar o estudo de chegar a pontos importantes sobre o tema abordado, afinal: "nem toda a descoberta pode ser explicada da mesma maneira, e procedimentos que deram resultado no passado podem causar danos quando impostos no futuro" (FEYERABEND, 2003, p.19). A pesquisa também se caracteriza como bibliográfica, que ocorre "se o desejo é formular e encontrar respostas em fontes bibliográficas do campo da educação e outros campos do saber" (TEIXEIRA E, 2005, p. 118). Entrementes, “a pesquisa bibliográfica é desenvolvida a partir de material já elaborado, constituído principalmente de livros e artigos científicos" (GIL, 1995, p. 71).

Por fim, também é dada ênfase no discurso considerando as relações entre discurso e poder, apresentadas pelo próprio Foucault (2013), salientando que em toda a sociedade a produção do discurso é, simultaneamente, controlada, organizada, selecionada e redistribuída por um número limitado de procedimentos que "têm por função conjurar seus poderes e perigos, dominar seu acontecimento aleatório, esquivar sua pesada e temível materialidade" (FOUCAULT, 2013, pp. 8-9). E isso é percebido ao longo da relação que pode ser feita entre a parresía e o discurso jornalístico, pois, querendo ou não, ele acaba se tornando uma forma de luta ideológica, objetivando um ideal que o seu autor - ou autores - busca transformando o mundo em que vive, bem 
como faziam os filósofos parresiastas da Grécia Antiga. Além disso, há uma relação direta entre discurso e parresía, como salienta o filósofo francês "A análise da parresía é a análise dessa dramática do discurso verdadeiro que revela o contrato do sujeito falante consigo mesmo no ato do dizer-a-verdade" (FOUCAULT, 2010b, p. 66).

\section{PARRESÍA JORNALÍSTICA: O QUE É?}

Antes de explicar o conceito de parresía jornalística, sistematizado por Ritter (2015), é pertinente fazer uma breve recuperação do significado do termo parresía. Como aponta Ritter (2015), o termo surge na Grécia Antiga, através da escola epicurista, para se referir à fala franca do sujeito no espaço público. Vale destacar que a palavra conta com uma ampla história, no entanto, neste artigo se trabalha com a perspectiva apontada nos cursos de Foucault, que se refere ao uso da fala franca no espaço público quando o sujeito assume riscos por proferir tal discurso. Para ficar mais claro, recorro à etimologia do termo, apresentada por Foucault:

Etimologicamente, parrhesía é o fato de tudo dizer (franqueza, abertura de coração, abertura de palavra, abertura de linguagem, liberdade de palavra). Os latinos traduzem geralmente parrhesía por libertas. É a abertura que faz com que se diga, com que se diga o que se tem a dizer, com que se diga o que se tem vontade de dizer, com que se diga o que se pensa dever dizer porque é necessário, porque é útil, porque é verdadeiro (FOUCAULT, 2010a, p. 327).

A partir disso, nos cursos proferidos entre 1981 e 1984, Foucault refletiu sobre o conceito de parresía. O termo é discutido nas falas do filósofo francês publicadas em formato de livro no Brasil com os seguintes títulos: A Hermenêutica do Sujeito - que compreende as aulas do período entre janeiro e março de 1982; O Governo de si e dos Outros - de janeiro a março de 1983; e A Coragem da Verdade - de fevereiro a março de 1984.

Na sua historicidade, Foucault (2010a) atenta para o surgimento do termo por parte dos epicuristas. No entanto, quem foram os epicuristas? Eles foram um grupo que seguia os ensinamentos de Epicuro de Sanos, filósofo do período helenístico na Atenas do século IV a.C. A partir de Epicuro se formou a escola epicurista que, segundo Foucault (2010), era organizada de acordo com uma hierarquia, que tinha em seu topo o próprio Epicuro. Diante disso, surge outra questão: quem foi Epicuro? O sujeito que levou esse nome nasceu no ano 342/341 a.C., em Samos, e morreu em Atenas em 270 a.C. Em 306 
a.C. mudou-se para Atenas, "lugar ideal para, como Capital do pensamento, difundir suas ideias" (ULLMANN, 2006, p. 20). Foi em Atenas que ele comprou o seu Jardim, local aonde criou a escola que tornaria os epicuristas conhecidos como filósofos do Jardim. "O Jardim não era um lugar de ociosidade, mas de treinamento para os que iriam a outros lugares semear suas ideias epicuristas" (Ibid.). Feita essa brevíssima contextualização sobre os epicuristas, ainda há uma questão central a ser respondida: como surgiu o termo parresía.

Ora, Foucault (2010) conta que Filodemo, um epicurista que viveu inicialmente em Atenas, mas que depois mudou para Roma por volta de 40 a.C., escreveu um texto raro, que se chamava justamente Perì parrhesía. A partir de então, pode-se começar a traçar uma história e uma sistematização para o significado de parresía, no sentido aplicável ao Jornalismo. A primeira definição do filósofo francês contemporâneo salienta que:

Parrhesía é a abertura do coração, é a necessidade, entre os pares, de nada esconder um ao outro do que pensam e se falar francamente. Noção, repito, a ser elaborada, mas que, sem dúvida, foi para os epicuristas, junto com a de amizade, uma das condições, um dos princípios éticos fundamentais da direção (FOUCAULT, 2010a, p. 124).

Foucault (2010a) coloca duas situações em que havia o uso da parresía na Grécia Antiga. A primeira é o sentido que Filodemo dá a parresía no texto recuperado por Foucault. Nesse texto, o filósofo epicurista trata da parresía como um franco falar que parte do mestre para os discípulos e que, difundida entre eles, passa a ser praticada por todos do grupo. Filodemo aborda a parresía como uma técnica. Assim, Foucualt (2010a) identifica dois pontos importantes sobre o sentido que o termo foi adquirindo: 1) a transferência da parresía do mestre para o discípulo; 2) a circulação da parresía entre os pares, nos meios epicuristas através da amizade, que é uma base desse grupo.

Tem-se, então, a parresía sendo tratada nesse momento como franqueza. Essa é uma das principais características que, independente do período histórico, está sempre presente em um discurso parresiástico: a fala franca.

Além disso, Foucault salienta que a parresía busca, em primeiro plano, dizer a verdade através da fala franca, mesmo que fazendo prescrições sobre os problemas abordados por essa verdade, e evita, assim, uma situação em que há o assentimento de todos, mas que, porém, não há mudanças. Tem-se, então, outro ponto importante da 
parresía que é fundamental para a aplicação dessa ideia ao jornalismo: o fator de transformação. "É preciso que essa verdade afete o sujeito, e não que o sujeito se torne objeto de um discurso verdadeiro" (FOUCAULT, 2010a, p. 217).

Para tanto, é preciso que o sujeito se torne a própria verdade. É preciso haver a confluência entre o sujeito e a verdade em seu discurso. E esse é um dos pontos centrais da parresía. Tem-se então o seguinte quadro: aquele que faz uso da parresía adota a fala franca - que se caracteriza pela forma como é expressa, sem lisonja e sem observar as regras da retórica - para alguém em uma posição hierárquica superior, com o objetivo de fazer com que o outro enxergue a verdade que lhe é dita para fazê-lo conhecer e cuidar melhor de si, tudo isso assumindo riscos. Porém, para tanto, deve-se observar o modo de vida daquele que pretende fazer uso da parresía. Foucault apresenta alguns pontos a serem observados para fazer essa verificação:

Há que se estar à espreita e, no momento em que se ouvir falar de alguém célebre, reputado, conhecido por não ser um lisonjeador, dirigir-se então a ele. Dirigir-se a ele, ou melhor, antes mesmo de dirigir-se diretamente a ele, tentar verificar, provar, testar de algum modo a não lisonja desse indíviduo. $\mathrm{E}$ observar como ele age na vida, observar se frequenta os poderosos, observar a atitude que tem em relação aos poderosos que frequenta ou em cuja dependência se encontra (FOUCAULT, 2010a, p. 356).

Esses dois pontos (o risco assumido e o modo de vida) estão fundados justamente na Apologia de Sócrates, de Platão. No texto, também mencionado por Foucault (2010a), Sócrates está sendo julgado pelos atenienses por cometer "crime, investigando indiscretamente as coisas terrenas e as celestes, e tornando mais forte a razão mais débil e ensinando aos outros" (PLATÃO, 2005, p. 59). E o que faz Sócrates para se defender? Mostra a relação que a sua vida tem com aquilo que ele diz, ao mesmo tempo assumindo o risco máximo, que vem a se confirmar com a sua condenação: a pena de morte. A relação da maneira de falar com o seu modo de vida, aliás, é ressaltada pelo filósofo logo no início do seu discurso de defesa:

Em verdade, nem conviria que eu, nesta idade, me apresentasse diante de vós, senhores, como um jovenzinho que prepara os seus discursos. E todavia, cidadãos atenienses, faço-vos um pedido, uma súplica: se sentirdes que me defendo com os mesmos discursos com os quais costumo falar nas feiras, na praça perto dos bancos, onde muitos de vós me tendes ouvido, em outros lugares, não estranheis por isso, nem provoqueis tumulto (PLATÃO, 2005, pp. 57-58). 
Nesse trecho pode se perceber esses dois itens, característicos do discurso parresíastico: 1) ao assumir que falará como sempre falou, Sócrates deixa claro que não aceita moldar o seu discurso para agradar ao público ou aos juízes e; 2) ao adotar tal postura ele assume o risco de não ser bem interpretado ou de não ter o seu ponto de vista aceito, assumindo, assim, a possibilidade de ser condenado à pena de morte - condenação esta confirmada ao final do julgamento. Essa fala franca de Sócrates é o que Foucault (2011) vai chamar de parresía socrática.

Tendo isso definido, há outra sistematização apresentada por Foucault (2010b) sobre a utilização discursiva da parresía. Ele chama essa sistematização de retântulo constitutivo. A forma geométrica ilustrativa é formada por quatro vértices. São eles:

1) Vértice constitucional: onde há democracia em que há igualdade entre os cidadãos;

2) Vértice político: onde há o jogo da ascendência ou da superioridade (uns têm mais poder do que outros);

3) Vértice da verdade: em que a tomada da palavra deve ocorrer para se dizer a verdade;

4) Vértice da coragem: onde há uma rivalidade, em que há dois polos - o que faz o discurso e aquele a quem o discurso é destinado em uma disputa moral.

Imagem 1: Forma geométrica proposta por Foucault (2010b).

\section{4)VÉRTICE \\ DA CORAGEM}

\section{1) VÉRTICE CONSTITUCIONAL}

\section{PARRESÍA}

\section{2) VÉRTICE POLÍTICO}

\section{3) VÉRTICE DA VERDADE}


Fonte: RITTER, 2015.

Essa sistematização, portanto, reúne alguns dos principais pontos da parresía da Antiguidade. E a partir dessa perspectiva apresento uma proposta de aplicação da parresía à prática jornalística, nos mesmos moldes apresentados em outras pesquisas realizadas, dentre as quais, a minha tese doutoral.

Para fazer tal recuperação, ressalto que, como fica clara na explanação de Foucault, a parresía socrática e epicurista, bem como outras não abordadas aqui (como a terapeuta e a cristã) são aplicadas a várias áreas, tais como a Filosofia e a Sociologia. Minha proposta, então, passa a ser a aplicação de tal conceito ao Jornalismo, tendo em vista que, tanto o jornalismo, quanto a parresía, ao menos ideologicamente se preocupam com a verdade e a fala franca, tendo em vista que esse é um valor universal, lembrando que, conforme salienta Gomes (2004, p.42) a busca pela verdade "norteará a atividade jornalística", incluindo o direito de resposta às pessoas envolvidas nas matérias, conforme exposto, e recuperado pela autora, no Código de Ética dos Jornalistas Brasileiros. Aliás, esse acaba sendo o norte de Joseph Pulitzer na sua defesa pela criação do curso de Jornalismo da Universidade de Columbia, em Nova York. "Um jornalista é o vigia da ponte de comando do barco do estado [...]. Não fica pensando em seu salário ou nos lucros dos proprietários. Está ali para zelar pela segurança e pelo bem-estar das pessoas que nele confiam" (PULITZER, 2009, p.27).

A partir do que foi exposto, apresento a sistematização que pode ser feita com as características que definem o jornalismo parresiástico. Assim, as cinco principais características elencadas a partir da noção de parresía que formam o jornalismo parresiástico são:

1) A fala franca;

2) A relação entre o discurso e a forma de vida do jornalista;

3) O uso da fala franca no espaço público através de discurso jornalístico (impresso, radiofônico, televisivo ou digital);

4) O locutor/jornalista assume riscos para fazer uso dessa fala franca;

5) Ato de coragem. 
Inicialmente, vale ressaltar que esses cinco elementos não são pensados isoladamente. Eles se interrelacionam. Eles se ligam, se cruzam e dialogam. Apenas um desses elementos pensandos isoladamente não constituem o discurso parresiástico no campo jornalístico. Sendo mais rigoroso: faltando um desses elementos, não há parresía jornalística. Ou seja, a parresía jornalística é o texto que contém os cinco elementos apresentados acima. Feita essa consideração, pensa-se no texto jornalístico de opinião como uma possibilidade para se exercer a parresía no campo jornalístico.

\section{TEXTO OPINATIVO: UM ESPAÇO PROPÍCIO PARA A PARRESIA NO JORNALISMO}

Ao abordar gêneros jornalísticos, Melo (2012) apresenta uma proposta com cinco categorias: informativo, opinativo, interpretativo, utilitário e diversional. Conforme apresentei em uminha tese doutoral, a parresía jornalística pode aparecer, por exemplo, em uma reportagem interpretativa. No entanto, nesse momento optou-se por restringir à análise ao gênero opinativo. E o que é o gênero opinativo no jornalismo? Conforme Melo, o gênero opinativo contempla denúncias, críticas e libelos. Em outra obra, abordando especificamente a opinião no jornalismo brasileiro, Melo (1994) salienta em que espaços a opinião aparece no jornalismo. Nessa sistematização, ele apresenta o editorial, o comentário, a resenha ou crítica, a coluna, a crônica, a caricatura e a carta como possibilidades. Fazendo um recorte ainda maior para a presente pesquisa, considera-se que Juremir Machado da Silva, nascido em 1962 em Santana do Livramento (RS), graduado em Jornalismo, doutor em Sociologia pela Universidade Paris V, Sorbonne, e atualmente professor do Programa de Pós-Graduação em Comunicação da PUCRS, colunista do jornal Correio do Povo e apresentador de programa radiofônico na Rádio Guaíba pratica alguns dos tipos de jornalismo opinativo apresentados por Melo.

O primeiro é o comentário, que informa rapidamente os fatos que estão acontecendo. "O comentarista geralmente é um jornalista com grande experiência e tirocínio, que acompanha os fatos não apenas na sua aparência, mas possui dados sempre disponíveis ao cidadão comum" (Ibid., p.105). Nesse sentido, Machado da Silva se vale de seu espaço diário e também de seu programa de rádio para expor os seus comentários. 
No impresso, Juremir frequentemente utiliza o espaço para praticar outros tipos de texto opinativo, tais como a própria coluna, que Melo (Ibid., p.136) define como"um mosaico, estruturado por unidades curtíssimas de informação e de opinião, caracterizando-se pela agilidade e pela abrangência”. A crônica também é um recurso frequentemente utilizado pelo professor e jornalista, afinal, a crônica é "uma narrativa circunsciadasobre os fatos observados pelo jornalista num determinado espaço de tempo" (Ibid., p.147). A resenha ou crítica também aparecem no espaço de Machado da Silva no jornal Correio do Povo. Entende-se por resenha ou crítica "uma apreciação das obras-dearte ou dos produtos culturais, com a finalidade de orientar a ação dos fruidores ou consumidores" (Ibid., p.125).

Caversan (2009), por sua vez, chama a atenção da restrição que há no número de jornalistas que conseguem exprimir a sua opinião nos grandes veículos. "São puquíssimos os jornalistas que podem escrever e publicar aquilo que pensam" (Ibid., p.76). Mesmo considerando a internet como um amplo espaço para a prática da parresía, não só por jornalistas, mas também por cidadãos comuns e políticos, o jornal ainda dá certa representatividade ao discurso proferido pelo autor. Pensando em uma estrutura de jornal impresso ou site jornalístico, Caversan apresenta dois tipos de textos de opinião no Jornalismo: 1) o colunista e 2) o articulista. O primeiro apresenta duas subdivisões: a) o jornalista de carreira que em determinado de sua vida profissional passa a ser colunista, e b) o jornalista que faz parte do grupo de colaboradores fixos do veículo, como personalidades do mundo político, intelectual, esportivo, etc. Já os articulistas se caracterizam por abordarem um tema específico: “esses colaboradores costumam ser selecionados pelos veículos por conta da atualidade de determinados temas ou por sua própria competência e/ou celebridade" (Ibid., p.78).

Esses espaços de opinião por, teoricamente, dar mais liberdade ao jornalista, tornam-se mais propícios para que o jornalista faça uso de sua parresía. Para fazer uso dessa parresía, porém, o jornalista, bem como era feito na Grécia Antiga, vale-se de técnicas narrativas e discursivas, pois há várias possibilidades de se falar o que se pensa. Um exemplo disso foi apresentado por Foucault em seus cursos, lembrando a forma como Platão diz a verdade para o Dionísio. Mesmo sem acusar o príncipe diretamente de ser 
injusto, Platão profere um discurso que causa a ira do tirano e a sua consequente venda como escravo.

A parresía deve ser procurada do lado do efeito que seu próprio dizer-averdade pode produzir no locutor, do efeito de retorno que o dizer-a-verdade pode produzir no locutor a partir do efeito que ele produz no interlocutor. Em outras palavras, dizer a verdade na presença de Dionísio, o tirano que fica furioso, é abrir para quem diz a verdade um certo espaço de risco, é abrir um perigo, é abrir um perigo em que a própria existência do locutor vai estar em jogo, e é isso que constitui a parresía (FOUCAULT, 2010b, p. 55).

Ora, no jornalismo opinativo, e mais especificamente no jornalismo opinativo brasileiro, há incontáveis casos de jornalistas e empresas que sofreram danos pessoais por terem feito uso de sua parresía em suas colunas, crônicas, resenhas, textos editoriais, etc. Um exemplo claro é o episódio envolvendo um desentendimento entre Juremir Machado da Silva e Luis Fernando Verissimo quando ambos eram colunistas do jornal Zero Hora, de Porto Alegre. É a partir desse caso que, a seguir, observo analiticamente algumas das características do discurso de Juremir Machado da Silva para entender se os textos selecionados aqui apresentam ou não as cinco características da parresía jornalística e, assim, caracterizá-los como um eventual uso da parresía na imprensa brasileira.

\section{JUREMIR MACHADO DA SILVA X LUIS FERNANDO VERISSIMO: A PARRESÍA NO JORNALISMO DE OPINIÃO}

O jornalista e professor Juremir Machado da Silva, atualmente trabalha como colunista do jornal Correio do Povo $^{3}$ (Porto Alegre-RS) e do site correiodopovo.com.br, como apersentador do programa Esfera Pública da Rádio Guaíba (Porto Alegre-RS) e como professor do Programa de Pós-Graduação da Pontifícia Universidade Católica do Rio Grande do Sul (PUCRS). Em 1995, quando era colunista do jornal Zero Hora ${ }^{4}$, principal concorrente do Correio do Povo, Machado da Silva escreveu uma coluna afirmando que estava em dúvida se comprava para um amigo um livro de Luis Fernando Verissimo ou um par de meias para lhe dar de presente de Natal. Tal texto foi o suficiente

\footnotetext{
${ }^{3}$ O jornal Correio do Povo, fundado em 1895 em Porto Alegre-RS, conforme levantamento da Associação Nacional dos Jornais (http://www.anj.org.br/maiores-jornais-do-brasil/) é o nono de maior circulação no Brasil e o terceiro de maior circulação no Rio Grande do Sul, com tiragem de 102.335 exemplares diários.

${ }^{4}$ Zero Hora, fundado em 1964, de acordo com a Associação Nacional dos Jornais é o sexto jornal com maior circulação no Brasil e o primeiro no Rio Grande do Sul, com tiragem de 152.573 exemplares por dia. O jornal pertence ao Grupo Rede Brasil-Sul (RBS), filial da Rede Globo no Rio Grande do Sul (http://www.gruporbs.com.br/).
} 
para iniciar um polêmico desentendimento com o escritor que resultaria na saída de Machado da Silva do Grupo RBS.

Esse caso é o tema de dois textos escritos por Juremir Machado da Silva e publicados no livro A miséria do jornalismo brasileiro, lançado em 2000. Assim, "O sistema os intocáveis" e "Um caso pessoal, ou em nome do filho" foram escolhidos para a presente análise, tendo como objetivo identificar se o jornalista fez uso de sua parresía e como ocorreu esse processo no discurso publicado em seus textos. Em outras palavras: que característica tem esse discurso, a priori, caracterizado como parresiásta?

Em “O sistema dos intocáveis”, Machado da Silva (2000) salienta que na polêmica discussão com Luis Fernando Verissimo ele acabou ingressando em um embate com um personagem da literatura brasileira que é considerado um mito. "Enfrentá-lo significa lutar contra os valores de um tempo" (MACHADO DA SILVA, 2000, p.102). E, como os gregos se levantavam diante dos tiranos e poderosos, o colunista entrou nesse enfrentamento, fazendo uso de sua parresía. Vale lembrar que, um dos adversários da parresía, conforme Foucault, é a lisonja.

\begin{abstract}
A conclusão é que a parrhesía (o franco-falar, a libertas) é exatamente a antilisonja. É a antilosonja no sentido de que, na parrhesía, há efetivamente alguém que fala e que fala ao outro, mas fala ao outro de modo tal que o outro, diferentemente do que acontece na lisonja, poderá constituir consigo mesmo uma relação que é autônoma, independente, plena e satisfatória. A meta final da parrhesía não é manter aquele a quem se endereça a fala na dependência de quem fala - como é o caso da lisonja. O objetivo da parrhesía é fazer com que, em um dado momento, aquele a quem se endereça a fala se encontre em uma situação tal que não necessite mais do discurso do outro (FOUCAULT, 2010a, p. 340).
\end{abstract}

A crítica ao pretenso humor dos textos de Luis Fernando Verissimo foi apenas o ponto de partida para a discórdia. Em outro texto, Juremir Machado da Silva criticou a falta de engajamento do pai de Luis Fernando, o escritor Erico Verissimo (1905-1975), em questões políticas de seu tempo. Diante do impasse, Verissimo exigiu de Machado da Silva uma retratação pública que, caso não fosse feita, resultaria na saída dele do jornal. Porém, Machado da Silva foi quem terminou optando por deixar o grupo RBS. "A timidez e a incapacidade de falar são os mitos relativos a Luis Fernando Verissimo. Quando sai da Zero Hora, em função da minha briga com ele, tive direito a um telefonema repleto de insultos por parte do bom moço" (MACHADO DA SILVA, 2000, p.103). Como a discussão se tornou pública, o discurso de Juremir Machado da Silva, além de ter 
franqueza e assumir riscos, também foi levado aos leitores do jornal, caracterizando-se, assim, como um discurso parersiastico.

É essencialmente o caráter público dessa afirmação, não apenas o caráter público, mas o fato de que essa parresía -nem sempre é o caso - se dá sob a forma de uma cena em que você tem: o tirano; diante dele o homem que fala, que se levantou ou que dá a sua lição e que diz a verdade; e, depois, em torno, há os cortesões cuja atitude varia de acordo com os momentos, a situação, que fala, etc. (FOUCALT, 2010b, p. 62).

Ou seja, a fala do jornalista, bem como a dos filósofos da Grécia Antiga - cada um a seu tempo -, ocore no espaço público, onde há a presença de um sujeito hierarquicamente em posição superior, seja por cargo ou por reprentação simbólica, e a de um público, seja presencialmente ou, contemporaneamente, através do consumo de conteúdos midiáticos. "A situação, inegavelmente, era de exceção. O sindicato dos jornalistas de Porto Alegre divulgou o contrário: atribuiu-me o telefonema e os insultos. Era mais coerente. Correspondia ao mito" (MACHADO DA SILVA, 2000, p.103). Machado da Silva, na visão da mídia, teria atacado o personagem mítico que encarna a figura do bom moço tímido e intelectual. Narrativamentese se cria o enredo do heroi contra um vilão. Vale reforçar que na parresía há "um dizer-a-verdade irruptivo, um dizer-a-verdade que fratura e que abre risco: possibilidade, campo de perigos, ou em todo caso eventualidade não determinada" (FOUCAULT, 2010b, p. 61). Assim, para fazer uso da parresía jornalística, o jornalista deve assumir todos os tipos de riscos.

No caso de Machado da Silva, o preço a ser pago foi o próprio emprego: "Critiquei Verissimo e paguei por delito de opinião. Errei ao não me demitir em caráter irregogável desde o instante em que me exigiu retratação [...]. Tentei mostrar-lhe que a sua chantagem me levava o desemprego" (MACHADO DA SILVA, 2000, p.103). Com a chantagem de Luis Ferando Verissimo, que exigia a retratação para não parar de escrever no jornal de maior circulação do Rio Grande do Sul, Juremir Machado da Silva fez a única coisa que um jornalista parreasista pode fazer nessa situação: ao invés de deixar os acontecimentos se desenrolarem nos bastidores, ele divulgou a polêmica.

[O parresiasta] só tem uma coisa a fazer: voltar-se contra o poderoso. E publicamente, diante de todos, diante do dia, diante daquela luz que os ilumina, ele se dirige ao poderoso e lhe diz qual foi a injustiça que este cometeu. E, nesse discurso da injustiça proclamado pelo fraco diante do poderoso, há ao mesmo tempo uma certa maneira de ressaltar o seu próprio direito, uma maneira também de desafiar o onipotente e, de certo modo, colocá-lo em duelo com a verdade da sua injustiça (FOUCALT, 2010b, p. 125). 
Juremir Machado da Silva acabou pagando o preço por se valer da fala franca no jornalismo. Em um espaço em que, teoricamente, ele poderia comentar livremente sobre outros autores, acabou criticando um colega de colunismo no jornal. Todavia, ele não deu o braço a torcer ou se rendeu à lisonja para salvar o emprego. "Não gosto do humor de Verissimo. Atrevi-me a ironizá-lo. Não se ri de um humorista. Caso isso ocorra, não deve exisitir vacilação: o herege deve ter a coragem de retirar-se" (MACHADO DA SILVA, 2000, p.103). Ora, tem-se aqui o típico caso de uso da parersía por parte de um jornalista brasileiro, afinal, o confronto com o mito resulta no ostracismo, em que o herege simbólico deve ser excluído do jogo.

No segundo texto selecionado para este artigo, "Um caso pessoal, ou em nome do filho", Machado da Silva revela a segunda etapa da polêmica: quando critica o pai de Luis Fernando, o escritor Erico Verissimo, pela falta de engajamento político em seu tempo. Nesse texto, ao contrário do primeiro, em que narra a polêmica com Luis Fernando, Machado Silva segue apresentando argumentos que justificam o seu posicionamento. "Na polêmica com LFV, ataquei também o seu pai, Erico Verissimo, afirmando que ele não teria brilhado pela coragem nos engajamentos políticos" (Ibid., 106). Por ocupar um espaço destinado ao jornalismo de opinião, teoricamente, ele estaria apenas cumprindo a sua função ao apresentar uma visão crítica de um personagem reconhecido na literatura brasileira. No entanto, diante da reação do filho do romancista, a publicação da opinião no espaço público passou a resultar em riscos a serem assumidos. "O mito venceu outra vez, coerente, irônico, compacto" (Ibid., p. 106).

Após a crítica de Juremir, as editoras da Universidade Federal do Rio Grande do Sul (UFRGS) e PUCRS, juntamente com a prefeitura de Porto Alegre, lançaram em 1997 o livro A liberdade de escrever, uma coletânea de entrevistas concedidas por Erico Verissimo ao longo de sua carreira. A iniciativa recebeu comentários elogiosos no jornal O Estado de São Paulo. O contraponto feito por Machado da Silva, numa nova tentativa de fazer uso de sua parresía, porém, foi barrado. "Enviei ao Estadão uma versão da análise que segue. Evidentemene, nenhuma linha foi publicada. Normal. O contrário não estaria na lógica da opinião assentada" (Ibid., p.106).

Porém, o jornalista e professor não se calou diante da recusa e, em "Um caso pessoal, ou em nom do filho" tornou pública novamente a sua crítica. "Na época da 
polêmica com Luis Fernando Verissimo, a esquerda gaúcha apropriou-se do debate e promoveu meu linchamento" (Ibid., p.106). Isso porque, segundo o autor, Luis Fernando Verissimo era um crítico do então presidente, Fernando Henrique Cardoso, o que o tornava um mito na esquerda brasileira. "Por que o petismo saiu em sua defesa? A resposta é simples: em nome do filho. LFV regenerou o pai. O inimigo número um do neolibral FHC transformou o pai num socialista" (Ibid., p.106). E, assim, o discurso de Machado da Silva e a polêmica com Luis Fernando Verissimo invadiu o campo da ideologia política. Machado da Silva, no entanto, manteve a sua opinião de criticar o posicionamento político de Erico Verissimo, divulgando, por exemplo, um manifesto colonialista e racista assinado pelo escritor em 1936 apoiando a invasão da Etiópia por Mussolni. "Considerou-se isso uma manobra dos inimigos de Erico. Não era para mexer no que estava esquecido" (Ibid., p.107). Para o autor, o romancista morto tornou-se mais do que um mito: virou intocável. E, para fazer uma crítica de caráter político a um escritor intocável é preciso assumir riscos, da mesma forma que os filósofos da Grécia Antiga assumiam para fazer uso da fala franca no espaço público.

\footnotetext{
O parresiásta dá sua opinião, diz o que pensa, ele próprio de certo modo assina embaixo da verdade que enuncia, liga-se a essa verdade, e se obriga, por conseguinte, a ela e por ela. Mas não basta. Porque, afinal de contas, um professor, um gramático, um geômetra podem dizer, sobre o que ensinam, sobre a gramática ou a geometria, uma verdade, uma verdade na qual creem, uma verdade que eles pensam. E no entanto, não se dirá que isso é parresía. Não se dirá que o geômetra ou o gramático, ao ensinar essas verdades em que creem, são parresiástas (FOUCAULT, 2011, p. 12).
}

Ou seja, para que haja a parresía é preciso que se acredite na verdade e no discurso proferido, ao contrário, por exemplo, da retórica, que pode fazer uso de diversas técnicas discursivas para passar uma impressão de verdade. O parresiásta diz a verdade porque ele, de fato, acredita na verdade que está sendo dita. E é por isso que ele assume riscos para manter o seu posicionamento.

Os parresiástas são os que, no limite, aceitam morrer por ter dito a verdade. Ou, mais exatamente, os parresiastas são os que empreendem dizer a verdade a um preço não determinado, que pode ir até a sua própria morte. Pois bem, está aí, me parece, o nó do que é a parresía (FOUCAULT, 2010b, p. 56).

Machado da Silva não chegou a morrer pela verdade, no entanto, pagou um preço alto para garantir a sua parresía em um dos poucos espaços em que a fala franca é admitida no Jornalismo: a coluna de opinião. Sabendo do poder simbólico que Luis 
Fernando Veríssimo tinha no jornal, ele não omitiu o que pensava sobre os textos do colega. Usou o seu espaço para falar sobre diversos temas, inclusive de literatura, para criticar o escritor. Foi criticado e ousou ainda mais: criticou o pai do escritor, considerado um dos maiores romancistas da literatura brasileira. Atacou dois mitos. Foi julgado e condenado vindo a perder o emprego. Mesmo assim, manteve a sua verdade e a sua fala franca publicando os dois textos aqui descritos e brevemente analisados. Enfim, fez uso de sua parresía.

\section{CONSIDERAÇÕES FINAIS}

Como foi visto, a fala franca e a busca pela verdade, ideologicamente, estão impregnados nas raízes do Jornalismo. No entanto, é notório que os discursos jornalísticos poucas vezes fazem uso da franqueza, incluindo os espaços de opinião. Neste artigo, busquei analisar algumas características do discurso de Juremir Machado da Silva em dois textos em que ele aborda a polêmica em que se envolveu com Luis Fernando Veríssimo nos anos 1990. O jornalista e escritor criticou a literatura de um colega de jornal que era intocável. Pagou caro por isso uma vez, mas mesmo assim manteve a sua opinião, defendeu a fala franca e fez uso de sua parresía, levando o caso até a última instância imposta por Luis Fernando Veríssimo à direção do jornal: ou ele, ou eu. Acabou sobrando para o mais novo e, naquele momento, menos prestigiado pelo público. $\mathrm{Na}$ perspectiva antiparresiástica, pode-se criticar aqueles com menos poder simbólico, porém, não se deve mexer com os poderosos. Juremir Machado da Silva não aceitou tal condição e pagou por expor publicamente a sua opinião.

Destarte, pode-se afirmar que sim, os dois textos de Juremir Machado da Silva são exemplos de parresía jornalística no Brasil, afinal, ele cumpre os requisitos propostos para um discurso ser considerado parresiástico. Primeiro, ele fala francamente e, mais do que isso, essa fala franca está diretamente relacionada à forma de vida do jornalista, que no caso, já se envolveu em outras polêmicas para manter a sua opinião. Segundo, o jornalista fez uso da fala franca no espaço público através de um discurso jornalístico, valendo-se de sua coluna de opinião. Terceiro, o jornalista assumiu riscos por fazer uso dessa fala franca no espaço público e, mais do que isso, acabou pagando um preço caro por isso. Por fim, Juremir Machado da Silva se valeu de uma das principais características 


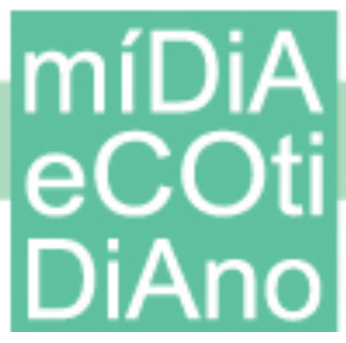

da fala parresiástica: teve um ato de coragem. Portanto, considero que os dois textos analisados nesse artigo são exemplos de parresía jornalística.

No entanto, ressalto que esse não é um caso único na história do jornalismo brasileiro. Outros escritores, como Fausto Wolff e Felipe Pena, por exemplo, também fizeram uso da parresía na imprensa. Historicamente, há outros exemplos: jornalistas que foram mortos e presos em períodos de ditadura, jornalistas que tiveram que deixar o país para nunca mais voltar ou que tiveram que se esconder para não serem torturados ou assassinados. Escolhi o caso de Juremir Machado da Silva por envolver um enfrentamento simbólico: um jornalista-escritor que ousou criticar um escritor famoso e querido do grande público.

Outras análises também são possíveis. Em Crônicas do golpe, o jornalista e professor Felipe Pena se expõe contra poderosos políticos. "Felipe, ele vai te processar e a tua vida vai virar um inferno, disse um amigo, jornalista e editor, quando anunciei o título da crônica" (PENA, 2017, p.17), escreveu, referindo-se ao texto "Quem tem medo de Gilmar Mendes?”. Esse é um caso de parresía jornalística no campo da política: um jornalista levanta-se no espaço público para apontar os erros dos poderosos políticos. Fausto Wolff, por sua vez, de maneira mais próxima ao caso de Juremir Machado da Silva, ousa criticar publicamente o jornalismo praticado pela grande mídia. Também pagou caro: nenhum jornal de grande circulação aceitava publicar os seus textos, semelhantemente como foi feito com Lima Barreto no início do século XX. "Nossa imprensa - os poucos jornais que sobraram e que viraram empregados dos canais de televisão - tornou-se clean, distante, superior, limitando-se a narrar os fatos sem atentar para os fenômenos que ocasionaram os fatos" (WOLFE, 2004, p.12). Todos esses são exemplos de outros casos que podem ser analisados sob a perspectiva de uma parresía jornalística.

Por fim, destaco que há um elemento importante para caracterizar esse tipo de parresía: a representatividade. Certamente com as mídias digitais criam-se diversos novos canais para que jornalistas façam uso de sua parresía. E muitos deles aproveitam esses espaços. No entanto, outra característica da parresía é que ela não só chega até a pessoa para quem o discurso é proferido, como também mexe com essa pessoa. E, tanto no caso de Juremir Machado da Silva, quanto nos outros dois citados brevemente, isso 
acontece. E por que acontece? Porque os textos ganharam representatividade. Os discursos proferidos por eles incomodam aos poderosos e repercutem. Esse parece ser um dos principais desafios para jornalistas que pretendem fazer uso de sua parresía. Aliás, é através da parresía que o jornalista cumpre uma de suas funções sociais: mostrar aos poderosos os seus próprios erros e denunciar para a sociedade as injustiças que ocorrem nos bastidores. E, para isso, mitos devem ser encarados. "Ao fortalecer os mitos, como forma de estimular o consumo de certos produtos, a mídia produz os intocáveis" (MACHADO DA SILVA, 2000, p.104). E, cabe ao jornalista parresiasta, enfrenta-los utilizando a sua parresía na própria mídia.

\section{Referências}

CAVERSAN, Luiz. Introdução ao jornalismo diário - como fazer jornal todos os dias. São Paulo. Saraiva, 2009.

FEYERABEND, Paul. Contra o método. Rio de Janeiro: Editora Unesp, 2003. FOUCAULT, Michel. A coragem da verdade. São Paulo: Martins Fontes, 2011.

. A ordem do discurso - aula inaugural no Collège de France, pronunciada em 2 de dezembro de 1970. São Paulo: Edições Loyola, 2013.

. A hermenêutica do sujeito. São Paulo: Martins Fontes, 2010a.

O governo de si e dos outros. São Paulo: Martins Fontes, $2010 \mathrm{~b}$.

GIL, Antonio Carlos. Métodos e técnicas de pesquisa social. São Paulo: Atlas, 1995.

GOMES, Mayra Rodrigues. Ética e jornalismo - uma cartografia dos valores. São Paulo: Escrituras, 2004.

MACHADO DA SILVA, Juremir. A miséria do jornalismo brasileiro - as (in) certezas da mídia. Petrópolis: Vozes, 2000.

MELO, José Marques de. A opinião no jornalismo brasileiro. Petrópolis: Vozes, 1994.

. Gêneros jornalísticos - teoria e práxis. Blumenau: EdiFurb, 2012.

PENA, Felipe. Crônicas o golpe. Rio de Janeiro: Record, 2017.

PULITZER, Jospeh. A escola de jornalismo - A opinião pública. Florianópolis: Insular, 2009.

PLATÃO. Apologia de Sócrates Banquete. São Paulo: Martin Clare, 2005.

RITTER, Eduardo. Jornalismo gonzo e parresía: mentiras sinceras e outras verdades. Porto Alegre: PUCRS, 2015 (tese de doutorado).

TEIXEIRA, Elizabeth. As três metodologias. Petrópolis: Vozes, 2005.

ULLMANN, Reinholdo Aloysio. Epicuro: o filósofo da alegria. Porto Alegre: Edipucrs, 2006.

WOLFF, Fausto. A imprensa livre de Fausto Wolff. Porto Alegre: L\&P, 2004. 